\title{
Constructing Meaning in Interaction through Picture Books
}

\author{
RÉKA LUGOSSY ${ }^{1}$
}

$\approx \quad$ This qualitative study describes and analyses young language learners' spontaneous comments while sharing picture books during EFL sessions. It also explores teachers' responses to learners' comments, and considers reasons teachers may choose to ignore children's talk in their first language (L1). Data were collected from young Hungarian learners (ages 5-12) and their teachers, through qualitative processes. The main findings give insights into the role of classroom talk in negotiating meaning in the foreign language and in developing literacy.

Keywords: classroom talk, meaning making, literacy, teacher's beliefs 


\section{Konstruiranje pomena pri interakciji s slikanicami}

RÉKA Lugossy

$\approx$ Kvalitativna raziskava opisuje in analizira spontane odzive mlajših učencev pri delu s slikanicami med učnimi urami zgodnjega učenja tujega jezika. Poleg tega so v analizo vključeni tudi odzivi učiteljev na komentarje učencev in ugotovljeni vzroki, zakaj se učitelji odločijo, da se ne bodo odzvali na govor otrok, ki je v maternem jeziku (J1). V raziskavo so bili vključeni mlajši madžarski učenci (5-12 let) in njihovi učitelji; uporabljen je bil kvalitativni pristop zbiranja podatkov. Izsledki nam omogočajo vpogled $\mathrm{v}$ pomen pogovora $\mathrm{v}$ razredu pri usklajevanju pomena besed $\mathrm{v}$ tujem jeziku in pri razvijanju pismenosti.

Ključne besede: pogovor v razredu, konstruiranje pomena, pismenost, učiteljeva prepričanja 


\section{Background to research}

David Nunan (1996, pp. 41-42) claims that "a great deal of research in our field is conducted in contexts where classroom noise either is unheard of or is considered irrelevant". This remark draws attention to processes that may pass for side-effects of the traditional IRF pattern of classroom interaction, and therefore often remain unexploited by research. This study aims to highlight the potential of student talk, which may at times rightly fall into the category of "classroom noise". The data presented and analysed here reveal that children spontaneously comment on what they hear and see while sharing picture books in English. These comments are most often in their L1. They may be on- or off-task, and teachers may find them funny, useful, or tiresome. However, comments indicate not only learners' willingness to interact, but also what students understand from the linguistic and visual input they receive.

Nikolov (2002) identifies commenting as a strategy often applied by children in making meaning of stories. In Oxford's terminology, commenting is a "combination of guessing intelligently on the basis of linguistic and other clues and translating" (Oxford, 1990, p. 176). Through this strategy, young learners contribute to the lesson by commenting on, most often in their L1, whatever they comprehend of the teacher's or one another's discourse. As commenting in the L1 may provide insights into how young learners make meaning of stories told or read in a foreign language, comments can be seen as resources through which teachers gain access to students' zone of proximal development, and mediate learning experiences for them.

Considering classroom talk in the conceptual framework of the sociocultural theory, Mercer and Howe (2012) argue that children's intellectual achievements depend not only on their efforts, but also on culturally situated forms of social interaction. This implies that classroom talk, if appropriately managed, has the potential to promote cognitive and linguistic development in the EFL class.

\section{Research questions}

I expected to find answers to the following research questions:

- What do learners' comments indicate about their attitudes towards sharing picture books in English?

- What do comments reveal about learners' meaning-making processes?

- How do teachers respond to learners' comments?

- What do teachers' responses reveal about their underlying beliefs about teaching and learning? 


\section{Participants}

In this study, I relied on data collected with young Hungarian learners aged 5-12 years. Data collection partly occurred in five classrooms where picture books were used with children between the ages of seven and twelve years during their EFL lessons at school. At the time of the study, five of the six teachers involved were participating in post-graduate training courses for in-service teachers, in which one of the tasks was to experiment with picture books in their lessons. While the sixth teacher, who was a native speaker of English, had had previous experience in this sense, it was the first time that the five Hungarian teachers had tried to use authentic picture books.

The pupils came from a variety of contexts, including socio-culturally disadvantaged areas from the neighbourhood of Pécs, Hungary, as well as schools situated in well-established areas of the town. Data were also gained from four young children (aged 5-8) with whom I shared picture books in their home environment. Anna (7) and Orsi (6) are children of close friends, while Kati (7-8) and Zsuzsi (5-6) are my own children. All four participants come from privileged backgrounds in terms of exposure to print and literate talk. Their story sessions in English were primarily meant to develop language awareness and positive attitudes towards the target language and culture.

\section{Data collection and materials}

In collecting data, I relied on qualitative processes, including direct observation, teachers' diaries, and informal discussions with teachers and learners, as well as self-observation. As qualitative studies are discovery-, rather than verification-oriented, and they work intensively with a small number of participants rather than large samples, the results are not generalizable to all contexts (Mackey \& Gass, 2005).

Observational data were collected in instances when teachers shared authentic picture books with their pupils. The chosen picture books provided good examples of authentic colloquial English, in visual and linguistic contexts, which made sense to children. The five teachers chose books that they thought best suited their learners' interest and linguistic level. These included A Dark, Dark Tale (Brown, 1992), The Three Little Wolves and the Big Bad Pig (Trivizas \& Oxenbury, 1993), Where the Wild Things Are (Sendak, 1963) and The Tiger Who Came to Tea (Kerr, 1998).

In contrast, the four very young learners, who chose the books themselves, opted for stories they expected to be interesting. I will present The Three 
Little Wolves and the Big Bad Pig (Trivizas \& Oxenbury, 1993), The Paper Bag Princess (Munsch \& Martchenko, 1980), and Snow White in New York (French, 1986) in greater detail when I discuss how the four children explored these texts.

All the books contained appealing pictures, which were also integral to meaning making (Marriott, 1998). Knowing that children's understanding of language is situationally linked (Donaldson, 1987), the pictures, the story-sharing frame and children's schemata of narratives were expected to compensate for the eventual language learners could not cope with.

\section{Procedures}

Data were collected between 1995 and 2007. In the first phase, I observed and tape-recorded one or two lessons with each participant teacher. Following this, I read teachers' notes and diaries, and carried out semi-structured interviews and informal discussions related to their experiences with using authentic picture books in their classes. As these discussions occurred in the teachers' L1 (Hungarian), they became involved spontaneously and naturally, and thus provided valuable data referring to their beliefs. As for the four young learners (aged 5-8) I taught, their longitudinal observation during the shared reading sessions and during other activities in their home environment, provided me not only with examples of comments they made during reading, but also with insights into their literacy development.

In the second phase, I re-read the collected data consisting of lesson transcripts, teachers' diaries, and my notes on the discussions with the teachers and on the interactive sessions with the four young children. Finally, I selected samples of interaction depicting students' comments and teachers' reactions to these comments, as well as teachers' opinions related to this point, and analysed the data. In what follows, I only focus on patterns of interaction selected according to the focus of this study, which explains why I do not draw on examples from all the teachers who were observed and interviewed.

\section{Results and discussion}

The collected data give insights into how children construct knowledge in the foreign language, while relying on their L1. A great amount of the comments revealed that children liked the pictures, as the most obvious and tangible facet of the story. Another category of comments uncovered children's reliance on pictures and on their schemata as basic meaning-making strategies. In this sense, the comments they made also revealed their attempts to explore 
the subtext in terms of inter-textual references, stereotypical representations and literary conventions. Finally, the children appeared to make some of their comments in order to sound "cool" and thus impress one another.

Another layer of the collected data refers to teachers' responsiveness to children's comments. There are examples suggesting that teachers prefer to ignore students' spontaneous contributions, while other samples of interaction show that teachers build on these comments, and support the construction of knowledge in interaction.

I will first look at what the comments reveal about children's thinking and learning, and then consider teachers' attitudes to children's comments, and explore underlying beliefs. In transcribing the interaction patterns the following coding has been adopted: S: student, T: teacher, A: Anna, O: Orsi, K: Kati, Zs: Zsuzsi, R: Réka (the researcher).

\section{Comments indicating intrinsic motivation}

Picture books invite instant personal engagement by their physical presence, mostly when they offer opportunities for interaction in terms of direct handling: children can lift flaps, look into mirrors, touch and smell various parts of the book, or simply enjoy the pictures. The samples of classroom interaction analysed below support children's spontaneous interest in picture books, as well as the role of pictures in scaffolding understanding of the text.

Transcript 1 depicts $\mathrm{T} 1$, ready to start telling A Dark, Dark Tale, while the eight-year-olds sitting around her in a circle are clearly more interested in labelling the pictures in Hungarian:

\section{Transcript 1}

1 T: Once upon a time...

2 S1: Sas! [Eagle!]

3 S2: Sas! [Eagle!]

4 S3: Bagoly! [Owl!]

5 T: Yes, it's an owl.

$6 \mathrm{~S}_{3}$ : Owl?

7 T: Yes, owl. It's an owl. Once upon...

8 S4: Rabbit!

9 T: OK, it's a rabbit. What else is there in the picture?

As it turned out from the follow-up discussion with the teacher, she initially thought that pupils would be mostly interested in the storyline. This was 
probably due to the fact that she was used to slightly older learners, who were willing and able to engage with the story faster. However, young learners were obviously pleased to linger on with the picture and enjoyed discovering the details. It appears from the tape that the teacher's "OK" in Turn 9 is not so much a positive reinforcement of the observation made by $\mathrm{S}_{4}$, but much rather her consent to change the plan, and allow students to go on with the self-initiated labelling activity.

Another example supporting children's fondness for visual details is exemplified in Transcript 2, in which the children identify details that are originally not in the teacher's focus. T1 chose to tell the story of The Three Little Wolves and the Big Bad Pig, a non-traditional version of the original Three Little Pigs and the Big Bad Wolf. T1 picked this book in spite of the demanding language, and she decided to retell it on the basis of the pictures. She had assumed that her pupils would easily make sense of the story, as they were familiar with the original version. She also believed that the children would find the new version funny because of the previous expectations related to their schemata of pigs-and-wolves.

The following extract presents the scene when, after repeated unsuccessful attempts to build a sturdy house that would keep them safe from the vicious pig, the wolves end up in a house made of flowers. As the pig has so far produced various unexpected items to destroy the wolves' houses (e.g., pneumatic drill, sledge hammer, dynamite), expectations should be focused on what is going to happen when the pig emerges next to the flower-house. However, it appears that at first reading eight-year-olds took more interest in the minute details, such as a little wolf escaping with the teapot, rather than the humorous aspects of the inverted story:

\section{Transcript 2}

$1 \mathrm{~T}$ : And he sniffed (sniffs)...the flowers. And the smell was so good that the pig became a good pig. ...

2 S1: A teás, itt is itt van. [Here's the teapot again.] (pointing at a tiny teapot in the corner of the picture)

3 S2: Tényleg, a teás... [Oh yes, the teapot...]

$4 \mathrm{~T}$ : He was a bad pig, but now he is a good pig.

5 S3: Ez nem ugyanaz a teás. [This is not the same teapot.]

$6 \mathrm{~S} 1$ : De az. [It is.]

7 T: Yes, it's the same teapot.

The remark in Turn 2 and the small dispute it elicits are clear indications of young learners' interest in the concrete aspects of stories and of their remarkable 
eye for detail. By repeatedly noticing the teapot, which is usually half-hidden by one of the characters, the children quickly identified a recurring pattern of the story. In terms of its implications for teaching, this extract also suggests the necessity of offering hands-on experience with the story while reading or telling the story to them. This strategy both focuses their attention by involving their interest for the tangible aspects, and it takes into consideration the typical way in which children explore pictures: starting with a tiny detail that my go unnoticed by adult readers, and gradually getting an overall view of the whole.

\section{Meaning making through comments}

As already pointed out, commenting in the L1 emerges as a crucial strategy in children's foreign language development (Nikolov, 2002). The following examples highlight the use of commenting as a meaning-making strategy in the EFL classes observed at school, where language development was the main aim. I analyse data from the four young learners I taught, and discuss the relevance of their comments in terms of exploring the subtext of the stories.

\section{Relying on pictures}

Illustrations may become a basic and most tangible source of information and may compensate for what learners cannot understand from the teacher's story-telling. As it appears from the following examples, students involved in prediction try to sort out what happened, in particular the feelings of a character in the story based on the picture, much more so than the teachers' discourse. The extract was recorded while T6 was supporting ten-year-olds in making sense of the passage when Max encounters the monsters in Where the Wild Things Are:

\section{Transcript 3}

$1 \mathrm{~T}$ : He is scared. Scared? ...

2 S1: ... biztos megijedt ... nézd, milyen arcot vág. [...he’s probably scared, look at the face he's making.] (pointing to the picture)

3 T: Yes, what happened?

4 S1: ... he ... (addresses peer:) Mi az a megijedni? Félni, megijedni? [What's the English for being scared? Being afraid, scared?]

5 T: Attila, show me, show me.

6 S1: (mimes)

7 T: Afraid.

8 S: Afraid, afraid of the boy. 
9 T: If you don't know the word (pointing to his head) show me. Say: (gesturing). And I'll tell you. Or you can say: Help me. Help me. Good.

In Turn 2, $\mathrm{S}_{1}$ explores the picture to make meaning of the story. Apparently, he lacks the English term for "being scared/afraid", which explains why he did not make sense of the teacher's explanation and question in Turn 1. In Turn 4, the same pupil uses the L1 as a compensation strategy, and also in order to ask for assistance. This extract is also interesting in that the teacher provides explicit strategy training, encouraging students to rely on communication strategies such as body language ("Show me"), and asking for assistance in English.

\section{Relying on previous knowledge}

Examples of classroom interaction also suggest that children processed new information while relating it to previous assumptions. Awareness of the story frame in general, and familiarity with the pre-text in the case of subversive versions of classical stories appeared to support children's understanding and thus supported linguistic recognition. This occurred in the instance depicted in Transcript 4: while sharing The Three Little Wolves and the Big Bad Pig, young learners made successful guesses about the story by relying on what they had already known from the classic version:

\section{Transcript 4}

1 T: The pig knocked at the door.

2 S1: "Who is it?"

3 T: "Who is it?" "It's the big bad pig. Little wolves, little wolves, let me come in." The wolves said ...

4 SS: "No!"

5 S2: Azt hiszi a farkasok nem ismerik a mesét. [He thinks the wolves don't know the story.]

6 S3: Ezt a mesét már ismerjük, disznó! [We’ve heard this tale before, pig!] (in a deep voice)

It appears that while ten-year-olds relied on their schemata of pigs-andwolves, they were also aware of the ironic tone in the story. They themselves made ironic remarks in Turns 5-6, in which they explicitly refer to the original pre-text, and imply that the pig is silly enough not to take into consideration what seems to be common knowledge about pigs and wolves.

Children's reliance on story schemata is further reinforced by their comments in the following example, in which $\mathrm{T}_{3}$ is reading The Tiger Who Came to 
Tea to twelve-year-olds whom she later described as communicative and motivated pupils. The extract depicts the beginning of the story, when Sophie and her mum are having tea, without suspecting that a tiger will soon join them.

\section{Transcript 5}

1 T: Suddenly, there was a ring at the door. Who's that?

2 S1: Grandmother.

3 S2: Uncle.

$4 S_{3}$ : Aunt.

5 S4: Megvan! A szomszéd! [I’ve got it! It's the neighbour!]

6 T: No.

$7 \mathrm{~S}_{5}$ : A detective.

$8 \mathrm{~T}$ : OK, I'll help. It was an animal.

9 S6: A cat.

$10 \mathrm{~S}_{4}$ :Te hülye, hogy kopoghatna egy macska? [How could cats knock on doors, silly?]

11 S7: Miért ne? [Why not?]

12 S6: A dog.

Although there are no explicit references to the books in the background, children betray traces of previous experiences of stories where cats and dogs knock and come in. It is worth noting that although this suggestion is turned down ("How could cats knock on doors, silly?"), there is instantly someone who legitimises reliance on knowledge gained from stories (Turn 11), and undaunted, S6 tries "a dog."

\section{Exploring the subtext}

A significant number of comments made by the four young children (aged 5-7) reveal their attempts to explore the multiple layers of meaning inherent in the picture books we read. Due to the limited language proficiency of the children involved, and the informal rapport between the teachers, the children felt free to ask and comment in Hungarian on whatever they felt important. This also explains why these sessions provided more opportunities to track down children's ideas about the stories we shared, more so than the more formal EFL lessons in which carrying on the interaction in the target language was a priority.

Whenever children's comments related to attempts to explore the subtext, or referred to their attitudes to literacy, I also chose to respond in the L1. I did this partly in order to maintain a natural atmosphere and elicit more comments on their attitudes to the book and the story-reading sessions in general. 
Moreover, these remarks revealed profound intuitions about the meaning of stories, and I felt it important to support the children in articulating these attempts to interpret the stories more clearly. Thus, these brief interactions presented good opportunities to work within children's zones of proximal development, and encourage further thinking in terms of concepts related to literacy.

The discussions carried on with the four children support Arizpe's findings, namely that looking at picture books involves wide-spectrum cognition, specifically: visual processing, analytical thinking, posing questions, and verbal reasoning (2006). As such, picture books develop children's cognitive abilities, including the use of language, and, as shown below, they also encourage multiconnectedness, by allowing us to relate to other contexts of human experience.

The books that proved to be most provocative in this sense are subversive versions of classic tales: The Three Little Wolves and the Big Bad Pig, The Paper Bag Princess, and Snow White in New York. By developing contrary to cultural expectations, these stories encourage re-thinking some of the ideologies (i.e., personal and cultural assumptions) attached to traditional fairy tales. Elizabeth in The Paper Bag Princess inverts all classical paradigms when she rescues her prince, and finally decides not to marry him. "Counter-cultural" versions of fairy tales (Zipes, 1983, p. 179) interrogate stereotypes related to gender roles or representatives of authority, and by doing so they encourage approaching traditional fairy-tale discourse in a creative way. Children's on-going remarks and queries support this point. The examples presented below show that these unorthodox versions of classical fairy tales challenged the children's previous experience related to character functions and the structure of the story, and thus stimulate children's imaginative and critical faculties. Thus, as "we read our lives into" fairy tales (Zipes, 1997, p. 1) and sort out our lives on the basis of these models, literature becomes a source of questioning the world, and ultimately, of fostering critical thinking. In what follows, I will focus on two aspects related to the potential of picture books to develop critical thinking skills: (1) challenging cultural stereotypes, and (2) developing visual literacy.

\section{Challenging cultural assumptions}

A good example of how unorthodox narratives support children in rethinking what they had taken for granted is shown by the way Kati (8) and Zsuzsi (6) received The Paper Bag Princess. Socialised from previous exposure to fairy tales into the idea that princes save princesses and marry them, both are slightly taken aback by the reversed pattern in which Elizabeth sets off to save Prince Ronald from the dragon, the prince is rude, and finally she decides not to marry him: 


\section{Transcript 6}

1 Zs: És nem szomorú, hogy nem megy férjhez a királyfihoz? [And isn't she sad that she doesn't marry the prince?]

$2 \mathrm{~K}$ : Lehet, hogy nem is igazi királyfi. [Maybe he isn't a real prince at all.]

3 R: Honnan gondolod? [Why do you think so?]

$4 \mathrm{~K}$ : Ök nem így szoktak viselkedni. [They don't usually behave like this.]

Turn 1 shows the impact of previous experience with fairy tales in which the heroes get happily married, and become masters of their existence as kings and queens (Bettelheim, 1991, p. 8). In Turns 2 and 4, Kati constructs an understanding of the new story based on a comparison with previous narratives, and gives evidence of deeper insights when she indirectly evaluates Ronald's behaviour. In the dialogue that occurred immediately after sharing the story, she also shows awareness of the two markedly different patterns in this genre: the "strange" kind and the "right" kind:

\section{Transcript 7}

$1 \mathrm{~K}$ : Azért furcsa mese, nem? Jó, hogy van ilyen, de az is jó, amikor rendesen van. [But it's still a strange story, isn't it? It's good to have one like this, but it's also good to have the right kind.]

2 Zs: Nekem ez jobban tetszik. Én is ilyen papírzacskót viselnék. Hát, igaz, hogy egy kicsit csúnya... de azért szép. [I like this one better. I would also wear a paper bag like this. Well, it is a little ugly... but it's nice.]

This extract also indicates how reading picture books may support children in shaping and articulating their ideas. Zsuzsi usually likes opposing her family, in particular her sister, and in this dialogue she finds a good opportunity to indicate her taste for the subversive (Turn 2), while she also displays the thinking that underlies original choices. Turn 2 also comes in support of Zipes's (1997) claim that children's literature, in particular fairy tale discourses, which develops contrary to cultural expectations, encourages original thinking, and thus offers an alternative to consumerism in society. This is also shown in the following dialogue, which occurred a few days after reading The Paper Bag Princess, when Zsuzsi brought up the issue again on the way home from kindergarten:

\section{Transcript 8}

1 Zs: De szerinted kihez megy férjhez? [But who do you think she will marry?] 
2 R: Ki? [Who?]

3 Zs: Hogy is hívták? [What was her name?]

$4 \mathrm{~K}$ : Elizabeth.

5 Zs: Igen, kihez megy férjhez Elizabeth? [Yes, who will Elizabeth marry?]

6 R: Nem tudom, Zsuzsi... Szerinted? [I don't know, Zsuzsi. What do you think?]

7 K: Olyan királyfihoz, akinek az tetszik benne, hogy... különleges. [A prince who likes her because she is... special.]

8 Zs: Igen... És én se mennék hozzá. És nekem se fehér ruhám lesz. Nem szeretem azokat a fehér drótos ruhákat. [Yes... I wouldn’t marry him either. And I won't have a white dress either. I don't like those weird white dresses.)

Finally, in Turn 8, Zsuzsi again expresses her sympathy for the subversive moves of the princess. Her identification with Elizabeth seems to help her articulate her own ideas, which go against cultural expectations related to wedding dresses, and is a good example of how young learners may learn to question shared assumptions, construct new understandings and thus develop critical thinking through reading picture books.

\section{Developing visual literacy}

Learning to read the pictures involves learning the conventions of representing the actual world, such as stylised forms or the connotations of colours. Stephens (1992) makes the point that viewers have to learn how to interpret or "read" a picture just as much as a verbal text, and that learning is part of acculturation. The following examples support this claim, and suggest that when making sense of visual representations, one relies on cultural assumptions.

The following dialogues occurred when my two children and I were reading Snow White in New York, which sets the classic story in the 1920s, with period ingredients (e.g., seven jazzmen). When seeing the stepmother painted in suggestive Art Deco style and harsh dark colours, five-year-old Zsuzsi remarked:

\section{Transcript 9}

1 Zs: Látszik, hogy gonosz. [You can tell she’s wicked.]

2 R: Honnan? [How?]

3 Zs: A színeiből. [By the colours.]

4 R: Miért [Why?] 
5 Zs: Csupa fekete és vérszínü. [She’s all black and blood-coloured.]

6 R: Ha jó lenne, milyen lenne? [What would she look like if she was good?]

7 Zs: Ilyen rózsaszín, meg pasztell. [Pink, like this one here, and pastel.] (points at the picture of Snow White in pink and white) Én is ilyen színekben járok, ugye? [These are the kind of colours I like wearing, too.]

$8 \mathrm{R}$ : Ez azt jelenti, hogy te is jó vagy? [Does this mean you are also good?]

9 Zs: Szerintem... [I guess so...]

Above, Zsuzsi discusses the characters based on the connotations of colours. While anthropological literature (Durand, 1966) suggests that our understanding of symbols (including colours) has to do with a deep, polarised and archetypal level of representation, it is also true that she has already grown into certain cultural conventions of representing the world. Her correct and natural use of the term "pastel" also suggests that she is used to attending discussions on such topics. Thus, both her previous background knowledge of Snow White, and her understanding and experience of the use of colours in books, suggested this interpretation.

An interesting addition comes in Turn 7, when Zsuzsi hints at her identification with the positive character. This is in tune with Bettleheim's point that the reason why children identify with heroes is because they find them attractive, not because they want to be virtuous (1991, pp. 9-10). However, it is precisely this identification that makes them operate on the level of language with abstract ethical concepts such as good and evil, and which therefore promotes an understanding of these concepts through social interaction.

\section{“Funny” comments: Meeting peers' expectations}

Data suggest that comments in the L1 were also made because children wanted to appear "cool" in front of their peers. Nikolov (2002) claims that while young children tend to accept the teacher as a model, around the age of 10-11 they want to meet peers' expectations rather than those of the teacher. Therefore, even when they have the necessary knowledge in the target language, they tend to add their comments in their L1, which functions as the vernacular style in the classroom context.

The wish to affirm their identities in front of their peers may also explain the preference of twelve-year-olds to work in groups, to ask peers for assistance rather than the teacher (Nikolov, 2002), and also to direct comments to one another, without involving the teacher. This was mostly the case with twelveyear-olds, who made abundant comments in the L1, which they then refused to 
repeat when $\mathrm{T}_{4}$ asked them to do so. Transcript 10, with the teacher retelling The Tiger Who Came to Tea, depicts twelve-year-old learners reinforcing group solidarity by making rather subversive comments:

\section{Transcript 10}

1 T: And Sophie's mum said: Sophie dear, go and open the door.

2 S1: (whispering to peer) Kis hülye kinyitja. [She'll open it, the little twit.]

3 S2: (in a loud whisper meant to be heard by peers:) Jaj, ne nyisd ki Zsófi, mer' a cukros bácsi lesz! [Don't open it, Sophie, 'cause it's the (approx.:) bogey-man...]

$4 \mathrm{~T}$ : What?

5 S2: Semmi. [Nothing.]

Whitehead (1995) observes that children produce subversive versions of traditional rhymes, games or behaviour patterns in order to discharge anxiety and to challenge adult power. In the extract above, the pupils challenge the social norms of the school environment on multiple levels. First, they interrupt the teacher's discourse, which, in the Hungarian school context goes against expected student behaviour. Second, they make their comments in L1 during the English lesson, when they are supposed to use the target language. Third, they refuse to cooperate with the teacher (Turns 2 and 5). Finally, they refer to concepts and use words which are considered taboo in an educational context. This is the case with the word "hülye" [twit], and also with "cukros bácsi", which approximately translates as "bogey-man", but also includes pedophilic connotations.

The data collected in classrooms suggest that boys tend to adopt a more provocative and sometimes rougher humorous style than girls. This is well exemplified by the extract above, in which the comments in Turns 2 and 3 were made by boys. It has also been noticed that while all students appear interested and involved when sharing picture books, boys tend to express their involvement loudly, and more vigorously than girls. The following extract is the continuation of Transcript 10, when $\mathrm{T}_{3}$ is sharing The Tiger Who Came to Tea with twelve-year-olds.

\section{Transcript 11}

1 T: Sophie opened the door, and saw a huge tiger. What did the tiger say?

2 Ss: Hello!

3 S1: Bejöhetek? [May I come in?]

4 T: Yes, may I come in? 
5 S2: Itthon van anyukád? [Is your mummy home?]

6 T: In English, Tomi. Is ...

7 S2: Is mother ... home?

$8 \mathrm{~T}$ : Is mother, or: Is your mummy home? Well, the tiger said to Sophie...

9 S3: (shouting) Csókolj meg, vagy megeszlek! [Kiss me or I'll eat you up!] (peers and teacher laugh)

While $S_{1}$ and $S_{2}$ try to predict the tiger's opening remark based on their schemata of "someone knocking at the door", S3 suggests an unexpected "Kiss me, or I'll eat you up!" Probably rooted in S3's memories of stories where wild animals threaten to devour little girls, the remark in Turn 8 sounds funny not only because it touches upon a taboo topic of the twelve-year-olds, but also because it is a combination of a common motif in classical cautionary tales, with something which seems out of place in the context of this children's story.

\section{Teachers' response to students' comments}

The collected data show that teachers' attitudes to learner talk vary: while some teachers consequently build on students' comments, others tend to ignore them. In what follows, I will present examples for both practices. First, I provide examples of teachers' ignoring students' spontaneous contribution, and explore their possible reasons for doing so. Then, I present situations in which teachers choose to react to children's comments, and thus create opportunities to support their language learning.

\section{Ignoring comments}

Some of the teachers found students' comments distracting, and therefore rejected them, or simply ignored them. One of the examples in this sense occurred when $\mathrm{T}_{5}$ was reading I Think my Mum's a Witch to a group of nineyear-olds. After brainstorming on animals associated with witches, the children received the book with visible excitement. The first page, with a picture of the witch wearing a pair of blue clogs, elicited a spontaneous comment, which was instantly turned down by the teacher:

\section{Transcript 12}

1 T: (reading the story) I think my mum's a witch. She has a white cat, but...

2 S1: Pont ilyen fapapucsot szeretnék! [This is exactly the kind of clogs I'd like to have...] 
3 T: Most ne a fapapucsot nézd, hanem arra figyelj, amit olvasok! [Stop looking at the clogs now, and listen to what I am reading!]

Although apparently off-task, the comment in Turn 2 is a sign of the speaker's spontaneous interest, which is otherwise seldom expressed in the framework of a lesson. It would be, as such a rare opportunity for the teacher pick up the topic nominated by the student, and thus both indicate interest and offer input in the target language, which is memorable because it was required by the students. Instead, the teacher's reaction sounds firm and prescriptive, and redirects students' attention to the only authority which has the right to nominate topics in the lesson.

As it turned out from the follow-up discussion with the teacher, this was indeed one of the underlying reasons that made her discourage students' comments: she believed that if they kept on "chipping in in Hungarian," she would never get anywhere with her plans. She also admitted that she was unfamiliar with the word "clogs" in English, and felt that without knowing the vocabulary item she could not react in any way to the comment. The next example will reveal some more about teachers' compensation strategies when they lack terms in the target language. As shown in Turn 7 of Transcript 13, the teacher spontaneously resorts to Hungarian when it comes to what she senses to be a discipline problem. This suggests that teachers may also resort to the $\mathrm{L} 1$ when they feel they do not have the appropriate language, or that they may lack the vernacular style in it.

In Transcript 13, the teacher deliberately misses the opportunity to build on students' comments, because of her underlying beliefs about the lesson frame and about learners' role. When reading the story of the tiger who came to tea and then ate and drank everything from the tea table, the fridge and the cupboard, T2 invited her twelve-year-old pupils to predict where the tiger went next:

\section{Transcript 13}

$1 \mathrm{~T}$ : Where did the tiger go next?

2 SS: Vécére. [To the toilet.]

3 T: No....Where did the tiger go?

4 SS: A vécére. [To the toilet.]

5 T: No! No!

$6 \mathrm{~S} 1$ : Szerintem is a vécére. [I also think he went to the toilet.]

7 T: Elég. [Stop it.] The tiger went away. (turns the page) He said: "Good bye." 
Although the children's suggestion sounds logical, with the tiger having eaten so much, and although it seems like a brilliant opportunity to teach vocabulary which is usually not presented in textbooks, the teacher avoids reacting to it. After her teaching she confessed that the remark made her angry, as she thought it was an inappropriate comment to be made in the lesson. To her misfortune, however, the more she tried to ignore it, the more children insisted on it, and the more it distracted children's attention. An interesting paradox is that the while this teacher was observed to resort to the $\mathrm{L} 1$ herself for various reasons, she was less likely to tolerate learners' comments in L2, and focused more on the form than on the content of learners' remarks.

\section{Building on comments}

The examples presented above suggest that by the spontaneous comments they make, children indicate their main points of interest related to the story, while also showing what they can make out from the teachers' discourse, and the gaps in their foreign language competence. As such, students' comments allow teachers to provide comprehensible input in the target language, on topics nominated by learners.

It appears then that building on students' comments is a mediating action which makes sense in the Vygotskian framework, where learning is seen as an essentially social activity. An ecological perspective on education also acknowledges "the extent to which people in classroom situations become environments and [...] resources for one another" (van Dam, 2002, p. 238), and thus generate new content and language. In this sense, teachers' responsiveness to students' contribution is an essential support in their development.

The following examples show how, instead of being seen as a nuisance, students' spontaneous contributions are seen as an opportunity for negotiating meaning and mediate learning. Transcript 14 provides a good example for the way the teacher scaffolds students' language learning, by responding to the comments which were only meant to be funny. The following interaction occurred after sharing The Three Little Wolves and the Big Bad Pig, and T1 tried to involve twelve-year-olds into predicting what the pig would do in the house of the three little wolves:

\section{Transcript 14}

$1 \mathrm{~T}$ : And what did they do in the house?

2 S1: Watched TV.

3 T: Maybe they watched TV. What else did they do?

4 S2: Megették a malacot. [They ate the pig.] 
5 T: Oh no! They didn't eat the pig. They were friends; you don't eat your friend, do you. Who's your friend? Is Tamás your friend? 6 S2: Yes.

7 T: And do you eat him for dinner?

8 S2: No. Csupa csont és bőr. [He’s only skin and bones anyway.]

9 T: Oh, is this why? Because he's only skin and bones?

10 Ss: (laughter)

By linking S2's vernacular to the institutional discourse (Turns 5 and 9), the teacher maintains interest, and avoids the development of a counterdiscourse that may hinder learning. More importantly, however, she indirectly indicates to students her willingness to involve them in the construction of knowledge, and by this, she invites further interaction. Thus, the teacher creates conditions for the emergence of language in interaction, which, according to research, is more valuable than environmental language, i.e., is mere exposure to language, for the following reasons: it focuses attention more than environmental language, it compels the speaker to make the input comprehensible, and it elicits immediate feedback and invites listeners to use the language (Blok, 1999).

\section{Conclusion}

The analysed data suggest that children spontaneously comment in their L1 while sharing picture books in English, and that these comments allow insights into both the cognitive processes that underlie the comprehension of narratives and into the way young readers grow into the culture of books and literate talk.

It has also become clear that teachers have an essential role in supporting learners to create meaning. Some of the participant teachers responded to learners' comments with interest and a good sense of humour, and considered learner talk as an opportunity to scaffold learning. From a sociocultural perspective, this dialogue in which the ideas of the participants are taken up and built on is crucial in transforming thinking. However, whenever teachers discouraged or ignored learners' comments, they missed out on opportunities which would otherwise have provided them access to the zone "where minds meet" (Cummins, 1994) and where meaning is constructed in interaction.

The study also suggests that teachers' underlying beliefs about teaching and learning largely influenced their perception of classroom talk and its benefits for learners' cognitive and language development. Therefore, the 
implications of this study point to the need for teacher education programmes to promote a dialogic model in teaching, where social interaction is considered crucial in children's intellectual development (Mercer \& Howe, 2012), and in teacher cognition.

\section{References}

Arizpe, E. (2006). Young interpreters: children's response to pictures. In J. Enever \& G. Schmid-

Schönbein (Eds.), Picture Books and Young Learners of English (pp. 35-48). München: Langenscheidt. Bettelheim, B. (1991). The uses of Enchantment: The meaning and importance of fairy tales. Fourth edition. London: Penguin.

Blok, H. (1999). Reading to young children in educational settings: A meta-analysis of recent research. Language Learning, 49(2), 343-371.

Brown, R. (1992). A Dark, Dark Tale. London: Random House.

Cummins, J. (1994). Knowledge, power, and identity in teaching English as a second language. In F.

Genesee (Ed.), Educating Second Language Children: The whole child, the whole curriculum, the whole community (pp. 33-58). Cambridge: Cambridge University Press.

Donaldson, M. (1987). Children's Minds. London: Fontana Press.

Durand, G. (1969). Les structures anthropologiques de l'imaginaire. Paris: Bordas.

French, F. (1986). Snow White in New York. Oxford: Oxford University Press.

Heath, S. B. (1992). Literacy skills or literate skills? Considerations for ESL/EFL learners. In D. Nunan (Ed.), Collaborative Language Learning and Teaching (pp. 40-57). Cambridge: Cambridge University Press.

Kerr, J. (1998). The Tiger Who Came to Tea. London: HarperCollins Publishers.

Mackey, A., \& Gass, S. M. (2005). Second Language Research: Methodology and design. Mahwah, New Jersey: Lawrence Erlbaum Associates, Inc.

Marriott, S. (1998). Picture books and the moral imperative. In Evans, J. (Ed.), What's in the Picture? Responding to illustrations in picture books (pp. 1-24). London: Paul Chapman Publishing Ltd.

Mercer, N., \& Howe, Ch. (2012). Explaining the dialogic process of teaching and learning: The value and potential of sociocultural theory. Learning, Culture and Social Interaction, 1(1), 12-21.

Munsch, R. N., \& Martchenko, M. (1980). The Paper Bag Princess. Toronto: Annick Press Ltd.

Nikolov, M. (2002). Issues in English Language Education. Bern: Peter Lang.

Nunan, D. (1989). Designing Tasks for the Communicative Classroom. Cambridge: Cambridge

University Press.

Oxford, R. (1990). Language Learning Strategies: What every teacher should know. NY: Newbury

House.

Propp, V. (1970). Morphologie du conte. Paris: Seuil.

Sendak, M. (1963). Where the Wild Things Are. London: HarperCollins Ltd.

Stephens, J. (1992). Language and Ideology in Children's Fiction. London: Longman. 
Trivizas, E., \& Oxenbury, H. (1995). The Three Little Wolves and the Big Bad Pig. London: Mammoth. van Dam, J. (2002). Ritual, dance, and play in a first English lesson: Bootstrapping a classroom culture. In C. Kramsch (Ed.), Language Acquisition and Language Socialization: Ecological perspectives (pp. 237-265). London: Continuum.

Whitehead, M. (1995). Nonsense, rhyme and word play in young children. In R. Beard (Ed.), Rhyme, Reading and Writing (pp. 42-61). London: Hodder \& Stoughton.

Zipes, J. (1983). Fairy Tales and the Art of Subversion: The classical genre for children and the process of civilization. New York: Routledge.

Zipes, J. (1997). Happily Ever After: Fairy tales, children, and the culture industry. New York: Routledge.

\section{Biographical note}

RéKa Lugossy is an Assistant Professor in English Applied Linguistics at the University of Pécs, Hungary. She has published in English mostly on the role of educational culture in language learning and teaching and on the role of narratives in children's meaning making and in teacher cognition. 